\title{
Study the Effect of Polypropylene Fiber with Steel Slag Aggregate in Concrete
}

\author{
Divya S Dharan', Aswathy Lal ${ }^{2}$ \\ ${ }^{1}$ PG Scholar, Structural Engineering, SBCE. \\ ${ }^{2}$ Assistant Professor, Department of Civil Engineering, SBCE
}

\begin{abstract}
India leading developing country in world. In future high strength high performance concrete required for construction work .Fiber-reinforced concrete (FRC) is concrete containing fibrous material which increases its structural integrity. The character of fiber-reinforced concrete changes with varying concretes fiber materials, geometries, distribution, orientation, and densities. Steel slag which is produced as a waste material in the steel industry and has a negative impact on environment when disposed. Steel slag was found to be the best replacement for fine aggregates of concrete. Making use of steel slag in construction industry helps for the mass utilization of waste material prevents the depletion of natural resources, cost reduction, protect and preserve environment. Polypropylene fiber is also a light weight synthetic fiber. It prevents crack formation and provides reinforcement to the concrete structure. In this project work polypropylene fibers of different percentage $(0.5 \%, 1 \%, 1.5 \%$, and $2 \%)$ added with optimum replacement of steel slag for the fine aggregate in concrete. Tests on workability, compressive strength, flexural resistance, split tensile strength, modulus of elasticity were conducted on specimens.
\end{abstract}

Keywords: Polypropylene Fibers, Steel Slag etc

\section{Introduction}

Conventionally concrete is mixture of cement, sand and aggregate. Properties of aggregate affect the durability and performance of concrete, so aggregate is an essential component of concrete. Fine and coarse aggregate constitute about $75 \%$ of total volume. It is therefore, important to use right type and good quality aggregate in concrete, because the aggregates the main matrix of concrete. Now a days aggregate are obtained from natural rocks which is decreases day to day. Therefore it becomes more necessary to find suitable sustainable alternative source to natural aggregates for preparing concrete. At present many steel plant are being set up across the globe causing a huge production of solid waste material like slag. Steel plants in India generate about 29 million tons of waste material annually, and 50 million tone worldwide. Now most of the industrial slag are being used without taking full advantage of their properties or thrown off rather than used. In accordance to chemical and mineral composition of the slag, these steel slag have cementations and/or pozzolonic property and can be potentially used as a main constituent of cement. Slag causes reduction in porosity of soil as well as permeability of soil thus causing water logging problem. The disposing of this material will have negative impact on environment.

Steel slag is industrial waste resulting from steel refining plants in conversion process. Owing to the large production, the research work for the last 30 years have shown that $65 \%$ of steel slag used today is for qualified fields of application. But remaining $35 \%$ of slag is still dumped. As a more active approach, slag can be used in the production of composite material of strength value 42.5 to $32.5 \mathrm{kN}$. The slag present in concrete satisfy physical properties which slows down the hydration of blended cement due to morphology and low calcium silicate content. Thus steel slag can be used in conventional concrete to improve its mechanical, chemical and physical properties.
The fiber dispersion into concrete is one of the technique to improve the building properties of concrete. Polypropylene fibers are synthetic fibers obtained as a by-product from textile industry. These are available in different aspect ratios and are cheap in cost. Polypropylene fibers are characterized by low specific gravity and low cost. Its use enables reliable and effective utilization of intrinsic tensile and flexural strength of the material along with significant reduction of plastic shrinkage cracking and minimizing of thermal cracking. It provides reinforcement and protects damage of concrete structure and prevents spalling in case of fire.

In this project polypropylene fibers of blended $(24 \mathrm{~mm}$, $40 \mathrm{~mm}, 55 \mathrm{~mm}$ ) type is used. The project deals with the effects of addition of various proportions of polypropylene fiber on the properties of concrete in fresh and hardened state. An experimental program was carried out to explore its effects on workability, compressive, flexural, split tensile strength and modulus of elasticity of concrete.

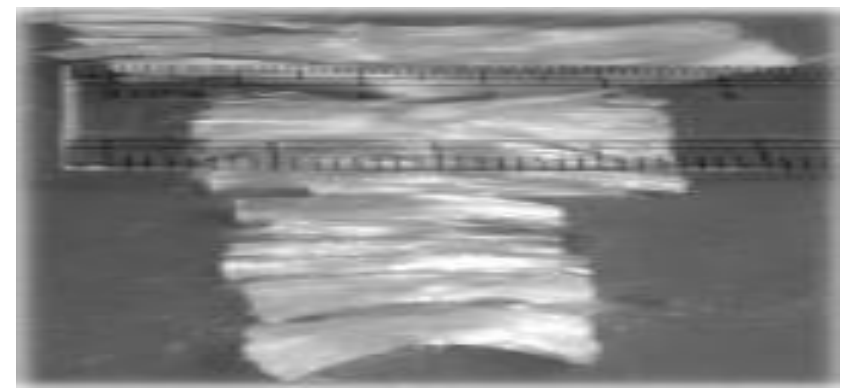

Figure 1: Blended (24mm, 40mm, 55mm) Polypropylene fiber

\section{Literature Survey}

\section{[1] Amena.I.Tamboli (2013)}

Investigates the different properties of locally available steel slag, a by-product obtained in the conversion process of iron to steel and utilizing this steel slag in concrete by replacing 


\section{International Journal of Science and Research (IJSR) \\ ISSN (Online): 2319-7064}

Index Copernicus Value (2013): 6.14 | Impact Factor (2015): 6.391

it partially with the cement keeping other parameters constant. Compressive strength and flexural strength on M20 grade of concrete with 0.5 water/cement ratio were investigated. Steel slag replacement $0 \%, 10 \%, 15 \%, 20 \%$ $25 \%, 30 \%, 35 \%$ are used. The best result for compressive strength was obtained at $20 \%$ and for flexural strength at $10 \%$ of replacement of cement with steel slag in concrete was obtained. Thus use of steel slag in concrete could enhance the strength in concrete.

\section{[2] Dr.K.Chinnaraju (2013)}

In this study an attempt is made to use steel slag, a byproduct from steel industry as replacement for coarse aggregate in concrete and eco sand which is a commercial by-product of cement manufacturing process introduced by ACC Cements as fine aggregate replacement. M30 grade of concrete was used. Possible optimum replacement of slag material was found to be $60 \%$ and possible optimum replacement for ecosand was found to be $40 \%$.It was concluded that replacing some percentage of coarse aggregate with steel slag enhances the strength.

\section{[3] Kolli.Ramujee (2013)}

The interest in the use of fibers for the reinforcement of composites has increased during the last several years. A combination of high strength, stiffness and thermal resistance favorably characterizes the fibers. In this study, the results of the Strength properties of Polypropylene fiber reinforced concrete have been presented. The compressive strength, splitting tensile strength of concrete samples made with different fibers amounts varies from $0 \%, 0.5 \%, 1 \%$ $1.5 \%$ and $2.0 \%$ were studied. The samples with added Polypropylene fibers of $1.5 \%$ showed better results in comparison with the others.

\section{[4] Milind V. Mohod (2015)}

This paper presents an experimental study on performance of polypropylene fiber reinforced concrete. In this study deals with the effects of addition of various proportions of polypropylene fibers on the properties of High strength concrete (M30and M40 mixes). An experimental program was carried out to explore its effects on compressive, tensile, flexural strength under different curing condition. The main aim of the investigation program is to study the effect of Polypropylene fiber mix by varying content such as $0 \%, 0.5 \%, 1 \%, 1.5 \% \& 2 \%$ and finding the optimum Polypropylene fiber content. A notable increase in the compressive, tensile and flexural strength was observed. However, further investigations were highly recommended and should be carried out to understand more mechanical properties of fiber reinforced concrete.

\section{Objective of the Work}

The objective is to study the effect of polypropylene fiber in concrete using steel slag as the fine aggregate replacement. To conduct a comparative study on steel slag, fiber in steel slag and conventional concrete.

\section{Methodology}

The methodology of the work consist of

1) Identifying the specification of material to be selected.

2) Collection of materials such as polypropylene fiber and steel slag.

3) Identifying the properties of collected materials. Various tests were conducted on cement, fine aggregate, coarse aggregate and steel slag are:

4) Selection of concrete grade.

5) Preparation of mix design of M30 grade concrete.

6) Cubes, cylinder and beams were casted with control mix using natural aggregate.

7) Preparation of test specimen with $0,25,30,35 \%$ of steel slag replacing fine aggregate.

8) Workability tests, compressive strength, tensile strength, flexural strength \&modulus of elasticity were conducted.

9) Optimum replacement of fine aggregate by steel slag was identified.

10) Preparation of test specimen by adding $0.5,1,1.5$ and $2 \%$ of polypropylene fibres with optimum replacement of steel slag for fine aggregate in concrete.

11) Workability tests,compressive strength, tensile strength, flexural strength \& modulus of elasticity of concrete were conducted.

12) Optimum percentage of fibre addition in concrete was determined.

\section{Material Test}

Table 1: Material Testing Results

\begin{tabular}{|c|c|c|c|}
\hline Test & Material & $\begin{array}{c}\text { Equipment } \\
\text { Used }\end{array}$ & $\begin{array}{c}\text { Values } \\
\text { Obtained }\end{array}$ \\
\hline $\begin{array}{c}\text { Specific } \\
\text { Gravity }\end{array}$ & $\begin{array}{c}\text { Ramco } \\
\text { cement (OPC } \\
43 \text { grade) }\end{array}$ & $\begin{array}{c}\text { Le Chatelier } \\
\text { flask }\end{array}$ & 3.2 \\
\hline $\begin{array}{c}\text { Specific } \\
\text { Gravity }\end{array}$ & $\begin{array}{c}\text { Fine } \\
\text { Aggregates }\end{array}$ & Pycnometer & 2.61 \\
\hline $\begin{array}{c}\text { Specific } \\
\text { gravity }\end{array}$ & Steel slag aggregate & Pycnometer & 2.67 \\
\hline $\begin{array}{c}\text { Specific } \\
\text { Gravity }\end{array}$ & $\begin{array}{c}\text { Coarse } \\
\text { Aggregates }\end{array}$ & Wire basket & 2.77 \\
\hline $\begin{array}{c}\text { Water } \\
\text { absorption }\end{array}$ & $\begin{array}{c}\text { Coarse } \\
\text { Aggregates }\end{array}$ & Vessel & $0.6 \%$ \\
\hline Workability & $\begin{array}{c}\text { M30 } \\
\text { concrete }\end{array}$ & $\begin{array}{c}\text { Slump cone } \\
\text { apparatus }\end{array}$ & $100 \mathrm{~mm}$ \\
\hline
\end{tabular}

\section{Mix Design}

Table 2: M30 Mix Proportioning

\begin{tabular}{|c|c|}
\hline Cement $(\mathrm{Kg} / \mathrm{m} 3)$ & 438 \\
\hline Fine aggregate $(\mathrm{Kg} / \mathrm{m} 3)$ & 695 \\
\hline Coarse aggregate $(\mathrm{Kg} / \mathrm{m} 3)$ & 1107 \\
\hline Water (li/m3) & 197 \\
\hline Water cement ratio & 0.45 \\
\hline \multicolumn{2}{|c|}{ Mix ratio $1: 1.59: 2.52: 0.45$} \\
\hline
\end{tabular}

\section{Experimental Investigation}

\section{A. Test Procedure}

Concrete test specimens consist of $150 \times 150 \times 150 \mathrm{~mm}$ cubes, Cylinders of $150 \mathrm{~mm}$ diameter and $300 \mathrm{~mm}$ height and 


\section{International Journal of Science and Research (IJSR) \\ ISSN (Online): 2319-7064}

Index Copernicus Value (2013): 6.14 | Impact Factor (2015): 6.391

100x100x500 beams. Concrete cube specimens were tested at 7 and 28 days to obtain the compressive strength of concrete. Cylindrical specimens were tested at 28 day to obtain the split tensile strength and modulus of elasticity of concrete. Beam specimens were tested at 28 day to obtain the flexural strength of concrete.

\section{B. Test on fresh concrete}

Workability is one of the physical parameters of concrete which affects the strength and durability as well as the cost of labour and appearance of the finished product. Concrete is said to be workable when it is easily placed and compacted homogeneously i.e. without bleeding or Segregation. The workability of concrete is measured by compaction factor test and slump test.

\section{Test on hardened concrete}

Various tests on hardened concrete is done to ensure the design strength of concrete and quality of concrete construction is achieved. It includes compressive strength test, flexural tensile strength test, split tensile strength test and modulus of elasticity.

\section{Experimental Results and discussion}

\section{A. Optimization of Steel slag}

Steel slag was replaced at different proportions such as $0 \%$, $25 \%, 30 \%$, and $35 \%$ respectively.

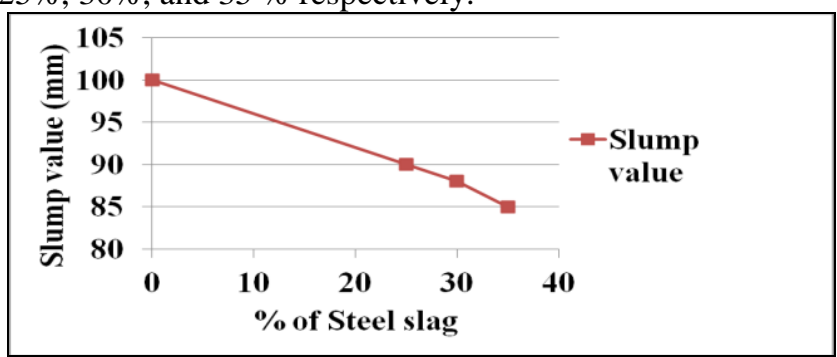

Figure 2: Slump value of M30 grade concrete

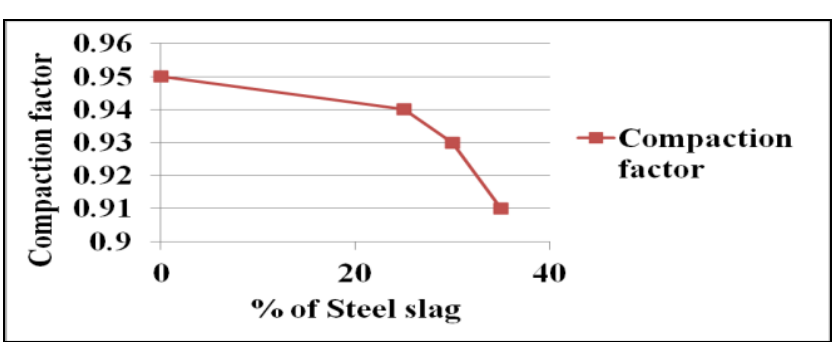

Figure 3: Compaction factor of M30 grade concrete

Table 3: Compressive strength of the specimens

\begin{tabular}{|c|c|c|c|}
\hline $\begin{array}{c}\text { S. } \\
\text { No }\end{array}$ & $\begin{array}{c}\text { \% Replacement } \\
\text { of steel slag }\end{array}$ & $\begin{array}{c}\text { 7days Compressive } \\
\text { strength }\left(\mathrm{N} / \mathrm{mm}^{2}\right)\end{array}$ & $\begin{array}{c}\text { 28days compressive } \\
\text { strength }\left(\mathrm{N} / \mathrm{mm}^{2}\right)\end{array}$ \\
\hline 1 & 0 & 25.20 & 38.50 \\
\hline 2 & 25 & 26.78 & 41.20 \\
\hline 3 & 30 & 28.29 & 42.81 \\
\hline 4 & 35 & 24.67 & 37.00 \\
\hline
\end{tabular}

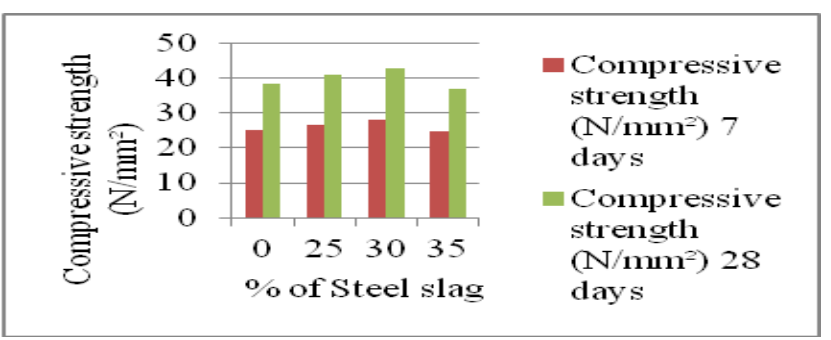

Figure 4: Compression value of concrete

Table 4: Split tensile strength of the specimens

\begin{tabular}{|c|c|c|}
\hline S.No & $\begin{array}{c}\text { \% Replacement of steel } \\
\text { slag }\end{array}$ & $\begin{array}{c}\text { 28days Split tensile strength } \\
\left(\mathrm{N} / \mathrm{mm}^{2}\right)\end{array}$ \\
\hline 1 & 0 & 3.42 \\
\hline 2 & 25 & 3.61 \\
\hline 3 & 30 & 3.76 \\
\hline 4 & 35 & 3.20 \\
\hline
\end{tabular}

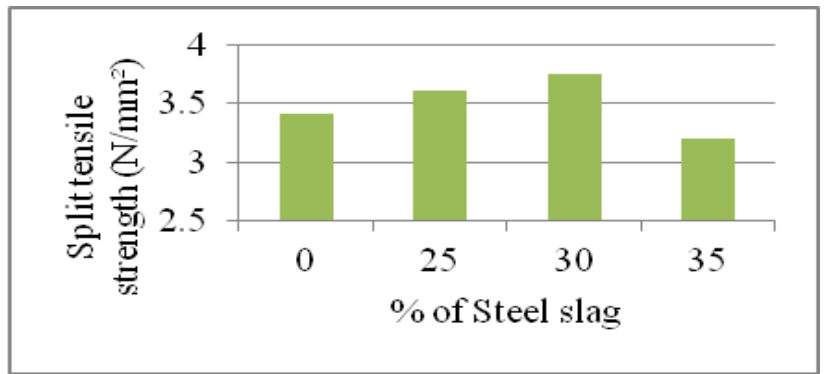

Figure 5: Tensile strength of the concrete

Table 5: Flexural strength of the specimens

\begin{tabular}{|c|c|c|}
\hline S.No & $\begin{array}{c}\text { \% Replacement of steel } \\
\text { slag }\end{array}$ & 28days Flexural strength $\left(\mathrm{N} / \mathrm{mm}^{2}\right)$ \\
\hline 1 & 0 & 4.34 \\
\hline 2 & 25 & 4.50 \\
\hline 3 & 30 & 4.72 \\
\hline 4 & 35 & 4.28 \\
\hline
\end{tabular}

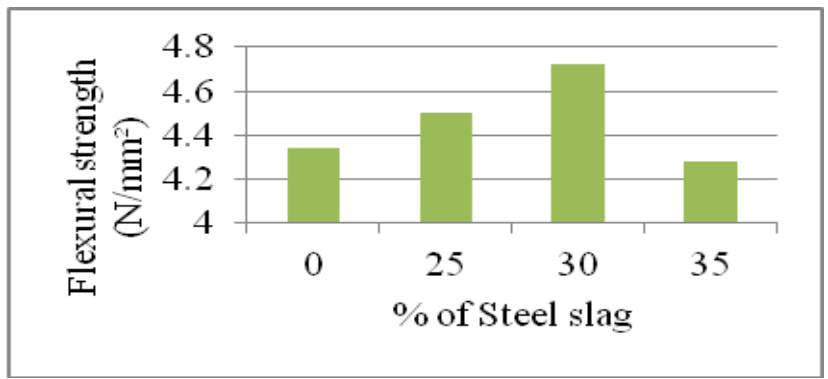

Figure 6: Flexural strength of the concrete

Table 6: Modulus of elasticity of the specimens

\begin{tabular}{|c|c|c|}
\hline S.No & \% Replacement of steel slag & Young's Modulus (GPa) \\
\hline 1 & 0 & 36.2 \\
\hline 2 & 25 & 38.0 \\
\hline 3 & 30 & 38.6 \\
\hline 4 & 35 & 34.4 \\
\hline
\end{tabular}




\section{International Journal of Science and Research (IJSR) \\ ISSN (Online): 2319-7064}

Index Copernicus Value (2013): 6.14 | Impact Factor (2015): 6.391

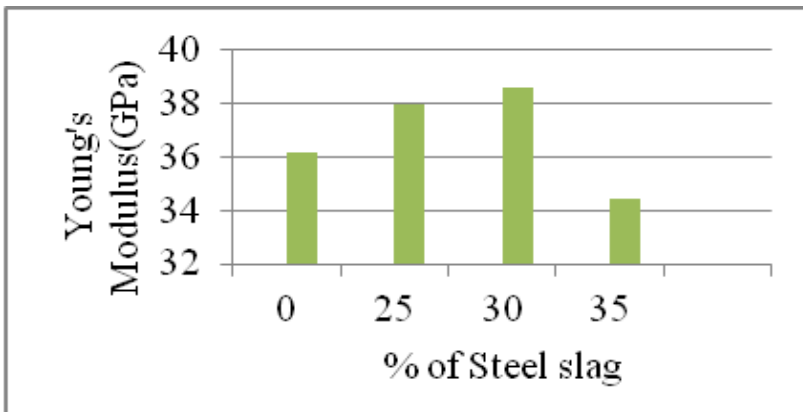

Figure 7: Modulus of elasticity

Found that the optimum level for the replacement of the steel slag was $30 \%$.

\section{B. Optimization of polypropylene fiber in optimum replacement of steel slag}

In this section polypropylene fiber (blended type- $24 \mathrm{~mm}$, $40 \mathrm{~mm}, 55 \mathrm{~mm}$ ) of different percentage added with optimum replacement of steel slag for the fine aggregate in concrete.

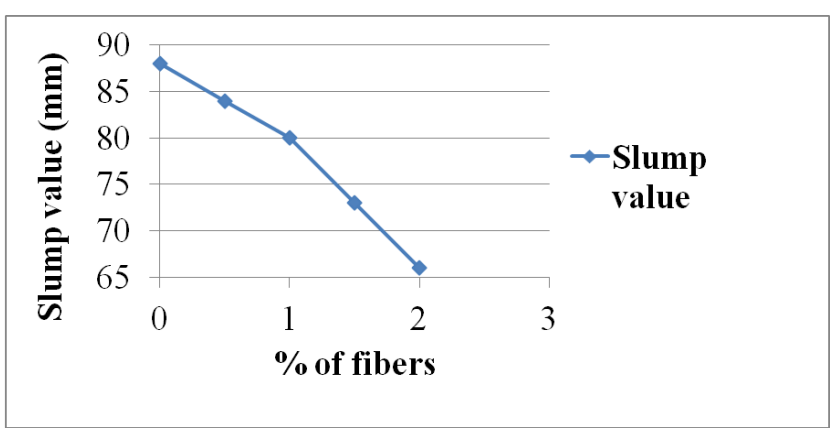

Figure 8: Slump value

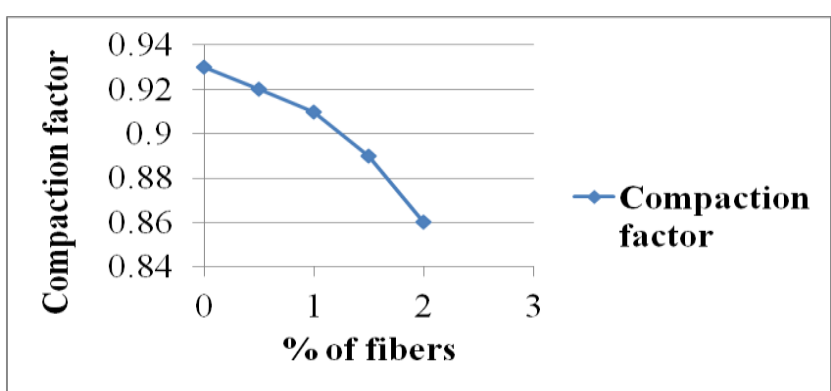

Figure 9: Compaction factor value

Workability decreases due to more addition of fibers, there is increases in amount of entrapped air voids due to the presence of fibers and therefore increase in air content attributes in reducing workability.

Table 7: Compressive strength of the specimens

\begin{tabular}{|c|c|c|c|}
\hline S.No & $\begin{array}{c}\% \\
\text { of fibers }\end{array}$ & $\begin{array}{c}\text { 7days Compressive } \\
\text { strength }\left(\mathrm{N} / \mathrm{mm}^{2}\right)\end{array}$ & $\begin{array}{c}\text { 28days compressive } \\
\text { strength }\left(\mathrm{N} / \mathrm{mm}^{2}\right)\end{array}$ \\
\hline 1 & 0 & 28.29 & 42.81 \\
\hline 2 & 0.5 & 30.32 & 46.32 \\
\hline 3 & 1 & 31.20 & 47.26 \\
\hline 4 & 1.5 & 31.86 & 48.20 \\
\hline 5 & 2 & 28.54 & 43.80 \\
\hline
\end{tabular}

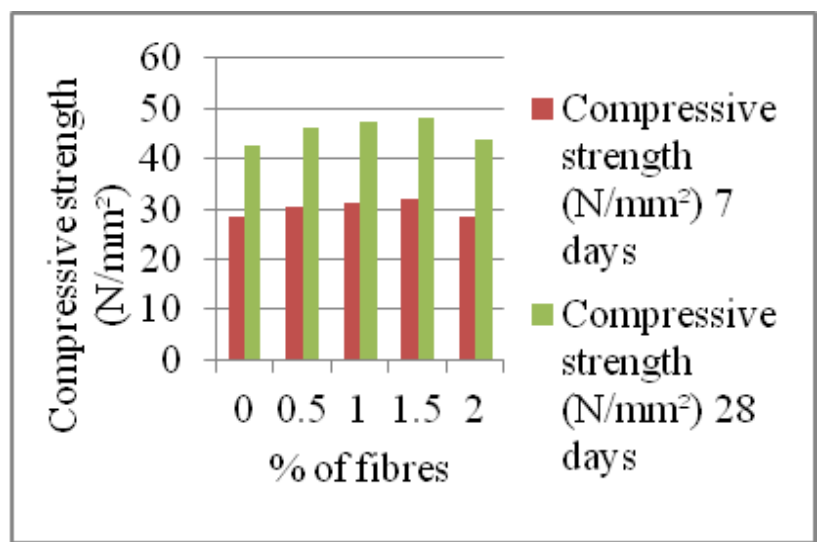

Figure 10: Compressive strength of concrete

Compressive strength increases for all dosages of fibers due to confinement provided by fiber bonding characteristics of concrete increases.

Table 8: Split tensile strength of the specimens

\begin{tabular}{|c|c|c|}
\hline S.No & \% of fibers & 28days Split tensile strength $\left(\mathrm{N} / \mathrm{mm}^{2}\right)$ \\
\hline 1 & 0 & 3.76 \\
\hline 2 & 0.5 & 4.34 \\
\hline 3 & 1 & 4.58 \\
\hline 4 & 1.5 & 4.62 \\
\hline 5 & 2 & 3.88 \\
\hline
\end{tabular}

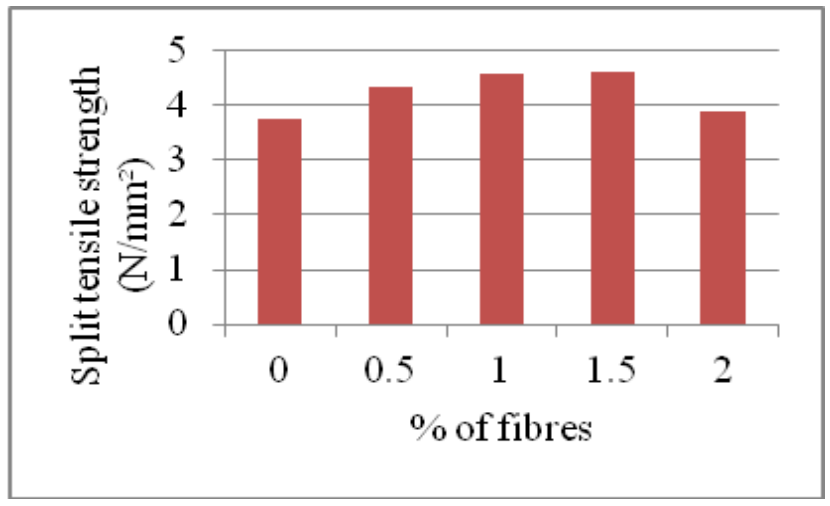

Figure 11: Tensile strength of concrete

Failure patterns of splitting tensile test indicate that specimens after first cracking do not separate unlike the concrete failure. Large damage zone is produced due to closely spaced micro cracks surrounding a splitting plane.Fiber bridging mechanism is responsible for such enhanced ductile failure pattern.

Table 9: Flexural strength of the specimens

\begin{tabular}{|c|c|c|}
\hline S. No & \% of fibers & 28days Flexural strength $\left(\mathrm{N} / \mathrm{mm}^{2}\right)$ \\
\hline 1 & 0 & 4.72 \\
\hline 2 & 0.5 & 5.64 \\
\hline 3 & 1 & 5.86 \\
\hline 4 & 1.5 & 6.12 \\
\hline 5 & 2 & 5.58 \\
\hline
\end{tabular}




\section{International Journal of Science and Research (IJSR) \\ ISSN (Online): 2319-7064}

Index Copernicus Value (2013): 6.14 | Impact Factor (2015): 6.391

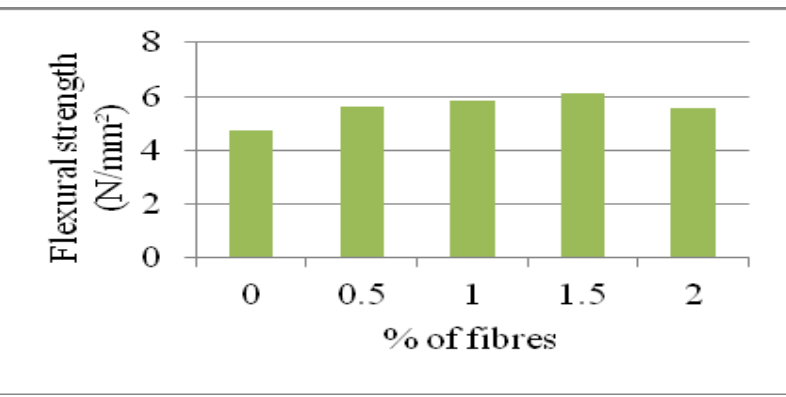

Figure 12: Flexural strength of concrete

The enhancement in flexural strength is achieved due to improvement in mechanical bond between the cement paste and fiber.As amount of fiber increases in mix, it greatly helps to reduce widening of cracks more effectively,thus resulting in increase in flexural strength.

Table 10: Modulus of elasticity of the specimens

\begin{tabular}{|c|c|c|}
\hline S. No & \% of fibers & Young's Modulus $(\mathrm{GPa})$ \\
\hline 1 & 0 & 38.6 \\
\hline 2 & 0.5 & 40.8 \\
\hline 3 & 1 & 41.6 \\
\hline 4 & 1.5 & 42.8 \\
\hline 5 & 2 & 40.4 \\
\hline
\end{tabular}

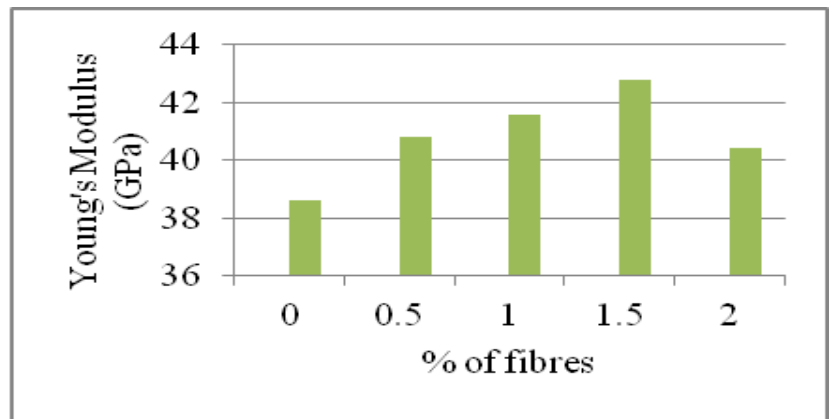

Figure 13: Modulus of elasticity

It is observed that by using $30 \%$ of steel slag with $1.5 \%$ fiber in concrete yields max. strength.

\section{Conclusions}

Based on the present study the following conclusions were derived:

Compressive strength of $1.5 \%$ of blended length polypropylene fiber reinforced concrete has found to be $21 \%$ increase in strength, when compared to that of Conventional concrete. Strength enhancement in split tensile strength is $26 \%$, flexural strength is $29 \%$ and modulus of elasticity is $15 \%$ compared to that of Conventional concrete. The experimental studies proved to be the best method or way in providing strong and durable concrete. It also gives solution to disposal problem of steel slag. It is observed that by using $30 \%$ of steel slag with $1.5 \%$ fiber in concrete yields max. strength. The following benefits can also be obtained:

- Cost reduction

- Social benefits

- Mass utilization of waste material

\section{Scope of Future Study}

Study on higher percentage replacement of steel slag for fine aggregate with blended type polypropylene fiber to achieve a mean target strength or not. Steel slag is available both granular and crystalline forms so it is used to replace both fine and coarse aggregate. In which to investigate the effect of fiber. Investigation on the flexural and shear crack pattern of fiber reinforced concrete with partial replacement of fine aggregate by steel slag.

\section{References}

[1] Abdulaziz I. Al-Negheismish, Faisal H. Al-Sugair and Rajeh Z. Al-Zaid (1996), "Utilization of Local Steel making Slag in concrete", Journal of Environmental science of sustainable society, Vol.1, pp. 39.

[2] Alizadeh R, Chini M, Ghods P, Hoseini M, Montazer and Shekarchi M (2003) "Utilization of electric arc furnace slag as aggregates in concrete", 6th ACI international conference on recent advances in concrete technology, Bucharest, Romania, June.

[3] Balaguru, P. N., and Shah, S. P., Fiber-Reinforced Cement Composites, Singapore, McGraw-Hill, 1992.

[4] Banthia, N., and Sheng, J.,"Fracture Toughness of Micro-Fiber Reinforced Cement Composites", Cement and Concrete Composites, Vol. 18, 1996, pp. 251-269.

[5] Bentur, A., and Mindess, S., Fiber Reinforced Cementitious Composites, London, Elsevier Applied Science, 1990.

[6] Dave U. V. and Desai Y. M. "Effect of Polypropylene, Polyester and Glass fibres on various strength of ordinary and standard concrete", The First International Conference On Recent Advance In Concrete Technology, Sep. 2007, Washington D.C. U.S.A.

[7] Deborah M. Proctor, Erinc, Shay, Kurt A. Fehling \& Brent L. Finley - "Assessment of human health and ecological risks posed by the uses of steel industry slag in the environment" - Journal of Human Ecological and Risk Assessment, Vol.8, Issue4, pp.681-711, 2002

[8] Ibrahim M, Qasrawi, Hishma Y, Shalabi, Faisal I - "Use of steel slag in asphalt concrete mixes" ASI, - Canadian Journal of Civil Engineering, Vol.34, Number 8, pp.902-911, NRC Research Press, $1^{\text {st }}$ August 2007.

[9] M.Maslehuddin,Alfarabi M.Sharif, et,al. "Comparison of properties of steel slag and crushed limestone aggregate concretes"-- Journal of Construction and Building Materials, Vol.17, Issue 2, pp.105-112, March 2003

[10]Troxel G.E, Davies H.E and Kelly J.W, Composition and properties of concrete (New York, McGraw Hill Books Company, 1968). 